\title{
Effects of the Income Stabilization Tool on farm income level, variability and concentration in Italian agriculture
}

\author{
Simone Severini ${ }^{*} \mathbb{D}$, Giuliano Di Tommaso ${ }^{1}$ and Robert Finger ${ }^{2}$
}

\footnotetext{
* Correspondence: severini@unitus.it ${ }^{1}$ Tuscia University, Viterbo, Italy Full list of author information is available at the end of the article
}

\begin{abstract}
This paper provides an ex ante assessment of the effects of the Income Stabilization Tool (IST), a new risk management tool proposed in the Common Agricultural Policy of the European Union. We investigate the effects of IST on income variability and levels as well as on income inequality in the farming population. We take Italian agriculture as an example as the introduction of IST is currently under discussion there. A rich panel of 2777 farms was studied over a period of 7 years. We use stochastic simulation to derive different income inequality estimates and apply Gini decomposition approaches to assess the distributional implications of IST. We compare the current income situation with that resulting from a hypothetical implementation of IST under different policy scenarios, also accounting for reduced levels of CAP direct payments. We find that IST not only stabilizes farm income but also enhances its level and reduces income inequality in Italian agriculture. IST is more effective in reducing income inequality when farmers pay contributions to mutual funds that are proportional to their income compared to the case of flat rate contributions. Finally, results do not support the hypothesis that the impact of IST will differ if the level of direct payments were to be reduced. Thus, results seem robust enough to accommodate future policy conditions.
\end{abstract}

Keywords: Agricultural policy, Income inequality, Income Stabilization Tool, Direct payments, Risk management

JEL classifications: D63, G22, Q12, Q18

\section{Introduction}

Current and future developments foreseen by the Common Agricultural Policy of the European Union (CAP) point in several directions, comprising (1) a shift towards more targeted and tailored payments, with particular emphasis on improving provision of a wide range of ecosystem services; (2) a reduction of support based on direct payments ${ }^{1}$; and (3) increasing support of market-based instruments to cope with the high and growing risk exposure of farms (e.g., Bureau et al., 2013, Galán-Martín et al., 2015, Meuwissen et al., 2018, Fresco and Poppe, 2016). Regarding the latter, the EU Rural Development Policy provides financial contributions (Bardaji and Garrido, 2016): to

${ }^{1}$ The recently proposed Multiannual Financial Framework for the period 2021-2027 envisages reductions in direct payments (European Commission, 2018; Matthews, 2018) 
premiums for insurance against economic losses to farmers, to mutual funds to pay financial compensations to farmers for economic losses, and to mutual funds managing an Income Stabilization Tool (IST) providing compensation to farmers for a severe drop in their income ${ }^{2}$. The focus of the paper is on the IST in Italy. Currently, Italy as well as Hungary and the Spanish region of Castilla y Leon are evaluating the possible implementation of this innovative tool. Yet it is not established in any of these countries, requiring ex ante assessments of possible implications (Bardaji and Garrido, 2016).

Existing studies on IST focus on its income-stabilizing effect (i.e. risk reduction), governmental costs, and potential beneficiaries within the farming population (EC, 2009; dell'Aquila and Cimino, 2012; Liesivaara, Myyrä and Jaakkola, 2012; Liesivaara and Myyrä, 2016b; Pigeon, Henry de Frahan and Denuit, 2012; Mary, Santini and Boulanger, 2013; Severini et al., 2018; Trestini et al., 2017 and 2018). Moreover, effects on farm income concentration have been provided (e.g. Finger and El Benni 2014a). Yet these studies have not addressed potential interdependencies between IST and direct payments and changes therein. Direct payments also influence income levels, stabilize farm income, and reduce income disparity within the farm population (Enjolras et al., 2014; Severini et al., 2018; Severini et al., 2016a and 2016b; El Benni et al., 2012; El Benni et al., 2016) ${ }^{3}$. Thus, the impact of IST could differ under different levels of direct payments.

In this paper, we contribute to the literature by providing an ex ante assessment of this tool for Italian agriculture. The aim of the analysis is to jointly quantify the potential effects of IST on income variability, income level and income concentration to provide a multidimensional assessment of this tool. Furthermore, this is done not only under the current situation but also under different direct payment reduction scenarios.

We use a panel data set for Italian agriculture consisting of 2777 farms observed over a period of 7 years. This allows an assessment of the distributional implications of IST by combining stochastic simulation, the estimation of various income distribution indicators and a Gini decomposition approach. The analysis compares the current income situation with that potentially resulting from the implementation of IST.

The remainder of the paper is organized as follows. The next section provides an explanation of the functioning of the IST. Methodology and data describes the methodology and the data used. Results and discussion presents and discusses the results of the analysis, while conclusions are put forward in the last section of the paper.

\section{Background on the functioning of the IST and its impact on farm income}

The IST is of particular interest to policy-makers because (1) it focuses on the key variable of interest, i.e., income; (2) it implicitly accounts for various correlations between prices and yields and across profits of different farm activities; (3) subsidization of IST complies with WTO green-box requirements; (4) it can also cover systemic risks (specifically price risk) that are not covered by purely commercial insurances thus

${ }^{2}$ Art. 39 of Regulation (EU) No. 1305/2013 of the European Parliament and of the Council of 17 December 2013 on support for rural development by the European Agricultural Fund for Rural Development (EAFRD) (OJ L 347, 20.12.2013).

${ }^{3}$ Reducing income disparity between EU Member States is another objective that is not considered in this analysis that focuses only on one MS. 
hampering the principles of risk pooling, (5) it is based on a public-private partnership (e.g., Bardají and Garrido, 2016; El Benni et al., 2016, Mary et al., 2013, Meuwissen et al., 2003, 2008, 2011, 2013; Liesivaara and Myyrä 2016a).

The IST schemes are going to be managed by mutual funds accredited by member states for farmers to insure themselves. A mutual fund creates a financial reserve through annual farmer contributions (regulated by each fund) and, if adverse events lead to income losses exceeding the threshold, the mutual fund compensates losses experienced by farmers. The rationale for the mutual fund is to deal with risks that are beyond the individual farmer's capacity to cope with (Cordier and Santeramo, 2018). Larger and more diverse mutual funds reduce the probability of occurrence of a large amount of indemnities to be paid in a specific year and thus also the costs for reinsurance (Severini et al., 2019). However, mutual funds restricted to farmers belonging on a specific sector and/or region may have the advantage reduce moral hazard problems because a less asymmetric distribution of information (Trestini and Giampietri, 2018).

The indemnification is defined as follows:

$$
\text { Ind }=\left(\begin{array}{lll}
0 & \text { if } & I \geq I_{R} \\
\beta \cdot(E-I) & \text { if } & I<I_{R}
\end{array}\right)
$$

where $I$ is the realized income for the year under consideration and $E(I)$ is the average income realized in the previous 3 years (see Finger and El Benni 2014b for discussions) and is calculated as follows:

$$
E(I)=\frac{1}{3} \sum_{t-3}^{t-1} I_{t}
$$

$I_{R}$ is the reference income that triggers indemnification for the year under consideration and it is defined as $I_{R}=\alpha \cdot E(I)$, where $\alpha$ is lower than one (e.g., 0.7) and reflects a deductible.

The coverage rate of IST is $\beta$ so that the indemnification paid is only a share of the actual income gap. These deductibles are used at two stages, i.e., the loss required to trigger a payout and a farmer's participation in the losses covered. Both deductibles reduce moral hazard behavior. The IST is going to have an impact on level and stability of farm income. Income of a generic farm for a given year is stochastic in nature $(\tilde{I})$ and can be represented as:

$$
\tilde{I}=\widetilde{\mathrm{MI}}+\mathrm{DP}+\widetilde{\mathrm{Ind}}-\mathrm{Cont}
$$

where $\widetilde{M I}$ is market income generated by the production activities net of CAP direct payments (stochastic because of production and price uncertainty) and DP is overall amount of CAP direct payments (deterministic, i.e., known to farmers).

When IST is in place, a farmer's income also includes the last two terms of (3): the indemnification and farmer contribution to the mutual fund (i.e., similar to an insurance premium). The sum of these two terms can be defined as the net financial benefits accruing to the respective farm derived from IST (i.e., $\mathrm{NB}_{\mathrm{IST}}=$ Ind - Cont). This can be positive or negative according to whether the farm receives an indemnification and to the amount of the contribution paid. 
This brief discussion of the potential income consequences of IST reveals some policy-relevant aspects. Firstly, IST is expected to reduce income variability. The probability of receiving indemnification and its level depends on several factors, including the distribution of farm gross margin as well as the extent of direct payments. Direct payments stabilize farm income (e.g., Cafiero et al., 2007; Finger and Lehman, 2012) since they are mainly derived from fully decoupled payments that are a relatively stable source of farm income (Severini et al., 2016b). Therefore, a large amount of direct payments is expected to lessen the likelihood that farm income will fall below the reference income level and will receive indemnities. This suggests that it would be interesting to assess the impact of the implementation of IST under different levels of direct payments.

Secondly, while the net financial benefit derived from IST is negative for farmers who do not receive indemnifications, the financial benefit for the overall group of farms is positive given that a share of the indemnifications is covered by public funds. This means that IST provides support to the overall group of farmers by enhancing their average income $e^{4}$.

Thirdly, as some farmers benefit from the IST because recipients of indemnifications, the others are negatively affected, the support provided by IST is not equally distributed among the farming population. Hence, IST is expected to have income distributional consequences. More specifically, if farms with lower expected incomes (e.g., Finger and El Benni, 2015, El Benni et al., 2016) are more likely to receive indemnification, the income inequality in the farming population can be presumed to decline.

Finally, the way farmers' contribution to the mutual fund is defined also affects how farm income is distributed within the farm population. The costs of the indemnifications not covered by public funds can be distributed among farmers according to different rules such as a uniform flat per farm contribution or a contribution proportional to the average income level of each farm. The two approaches are expected to result in a different distribution of costs and benefits of the IST.

\section{Methodology and data}

Motivation of the methodological approach

We empirically test and quantify the potential short-term consequences of the application of IST by using a large sample of farms. This allows us to provide nationwide results and to address income inequality consequences of IST that clearly requires a large sample of farms if useful insights are to be obtained (e.g., Finger and El Benni, 2014a; Liesivaara et al., 2012; Mary et al., 2013; Severini et al., 2018). We focus on a simulation approach that is applicable to a large sample (e.g., Keeney, 2000; El Benni et al., 2016; Severini et al., 2018) instead of focusing on a farm-modeling approach which usually concentrates on a few representative farms (see e.g., Turvey, 2012; Castañeda-Vera and Garrido, 2017). As in previous analyses (e.g., Severini et al., 2018; Finger and El Benni, 2014a and b; El Benni, Finger and Meuwissen, 2016; European Commission, 2009; Liesivaara, Myyrä and Jaakkola, 2012), we assume mandatory participation, as the question of participation is left open by the EC. Along these lines, Matthews (2010) remarks that, given the substantial

${ }^{4}$ Participation in IST could also generate transaction costs that negatively affect farm income. Therefore, simulations have been developed to consider this issue. Results are referred to below in the text and in the Appendix. 
public subsidy involved in CAP risk management tools (such as IST), not many farmers would opt out of such a scheme.

The effect of IST on production choices is not modeled ${ }^{5}$. Hennessy (1998) provides a theoretical framework to analyze the impact of income support policies under uncertainty. A farmer is assumed to maximize his/her expected utility of income (profit) which also includes government support such as the CAP direct payments (which are mostly decoupled from production). However, IST will also provide support to farmers. As shown by Hennessy (1998), even if the amount of support were fully decoupled from production choices (e.g., input use), it still influences producers' choices if the expected marginal utility depends on the level of profits. Indeed, if the support was dependent on the source of uncertainty, as it is clearly in the case of IST, this may cause an increase in production (input use) (Moro and Sckokai, 2013). Despite the potential relevance of this issue, very few analyses have assessed the potential implication of IST on farmers' production choices (e.g., Mary et al., 2013) or decisions regarding the use of alternative risk management tools (Lougrey et al., 2016; Castañeda-Vera and Garrido, 2017). All these studies listed above refer to a very limited number of individual or representative farms neither allowing to extend results to the whole farm population nor analyzing income distribution consequences (e.g., Finger and El Benni, 2014a; Liesivaara et al., 2012; Mary et al., 2013; Severini et al., 2018). There is a tradeoff between the detailed representation of farmers' decision and the number of farms considered, especially due to data limitations and requirements to consider farm-specific decision-making under risk (e.g., Turvey, 2012; Mary, Santini and Boulanger, 2013).

\section{Empirical strategy to assess income consequences of IST}

The effect of IST is assessed by comparing the observed income (i.e., including CAP direct payments but without IST) with the income that could be generated with IST in place in each of the farms in the sample. We consider three different scenarios described in Table 1.

The baseline scenario $I$, i.e., with direct payments but without IST, reflects current conditions as observed in our sample. We assume a single nationwide mutual fund will manage the IST (see Severini et al. (2018) for discussions and alternative specifications of the mutual fund). Farmers have to pay a contribution to the mutual fund. In scenario IIF and IIP (Table 1), farmers pay contributions that are set to recover $35 \%$ of the indemnifications paid by the mutual fund provided that up to $65 \%$ of these is covered by public funds ${ }^{6}$. Farm-level contributions to IST are not yet legally specified. Thus, two scenarios are used. Firstly, as proposed by Finger and El Benni (2014a), we simply

\footnotetext{
${ }^{5}$ Future research could explore the potential impact of IST on the behavior of risk-averse farmers. However, this requires a relatively large amount of additional data including, primarily, the extent of the farmers' risk aversion and this data is currently not available. Note that farmers are expected to have different risk preferences (see e.g., Iyer et al., 2019, for an overview). Therefore, it would be inappropriate to apply the same risk aversion level to all farms as simulation results would be strongly driven by the imposed assumptions.

${ }^{6}$ The main simulation assumes that there are no additional costs to be charged to farmers. However, scenarios supposing that farmers incur additional transaction costs have also been developed. Results of these simulations do not alter the main findings of the analysis (see Tables 10 and 11 in the Appendix).
} 
Table 1 Description of the simulation scenarios referring to the implementation of the IST

\begin{tabular}{ll}
\hline Code & Description \\
IIP & Baseline: current observed situation, including CAP direct payments, but without the IST in place \\
IIF & IST with farmers paying a flat rate contribution to the mutual fund \\
II & $\begin{array}{l}\text { Theoretical case in which the IST is fully subsidized (i.e., farmers do not pay any contribution to the } \\
\text { mutual fund). }\end{array}$ \\
\hline
\end{tabular}

divide the $35 \%$ of the total indemnifications paid by the mutual fund in each of the years $\left(\operatorname{TInd}_{t}\right)$ by the number of farms in the sample $(n)$ :

$$
\operatorname{ContF}_{t}=0.35 \cdot \operatorname{TInd}_{t} / n
$$

ContF $_{t}$ is the flat rate contribution paid by the farmers to the mutual fund (IIF in Table 1). In a specific year, each farm pays the same contribution regardless of its size and the probability that it will receive an indemnification. Flat rate insurance premiums are used, for example, in the catastrophic crop insurance program in the USA (e.g., Shields, 2015).

However, when farms vary markedly in terms of size, as in the case of Italy, it seems very unlikely that all of them will be charged the same amount ${ }^{7}$. Therefore, in scenario IIP we calculated farm-specific contributions by distributing the IST cost charged to farmers in proportion to their average income. The proportional contribution paid by the $i$-th farmer in the $t$-th year is calculated as:

$$
\operatorname{ContP}_{i t}=0.35 \cdot\left(\operatorname{TInd}_{t} / \mathrm{TE}_{t}\right) \cdot \mathrm{E}_{i t}
$$

where $\mathrm{TE}_{t}$ is the sum of the average incomes of farmers.

Hence, $\mathrm{TInd}_{t} / \mathrm{TE}_{t}$ reflects the average indemnification rate of IST in year $t$. Note that such configuration seems more appropriate for the case of Italy. Therefore, the discussion of the results will focus only on this scenario.

Finally, an additional scenario considers the hypothetical case in which IST is fully subsidized (II in Table 1). While this scenario is ruled out by EU Regulation, it is used to isolate the impact of the role of the farmers' contributions by comparing results referring to scenario $I I$ with that of scenarios IIF and IIP.

The consequences of the implementation of IST have been assessed also under scenarios considering reduced levels of direct payments. These scenarios have been developed by applying the same relative reduction (\%) to the level of direct payments received by each farm in the baseline conditions ${ }^{8}$. This simulation exercise allows to assess the impact of IST in hypothetical conditions of lower direct payments support. This is justified by the fact that, according to the recently proposed Multiannual Financial Framework for the period 2021-2027 (European Commission, 2018), the level of direct payments will likely be lower than in the past.

\footnotetext{
${ }^{7}$ This also seems to comply with actual practices in subsidized farm insurances whereby the premium is defined as a share of the value of the insured production (Bardají and Garrido, 2016; Castañeda-Vera and Garrido, 2017).

${ }^{8}$ Reducing direct payment not uniformly within the farm population (e.g., more in some types of farming than in others) could result in different results.
} 


\section{Approaches used in the analysis}

The income stabilization effect of IST is assessed using the coefficient of variation of farm income calculated for each individual farm over the years from 2012 to 2015 . The income enhancement role of IST is assessed by simply comparing the average income level of the farms in the sample over the same period. In both cases, the analysis is based on the comparison of the conditions with and without IST in place.

Income distributional consequences of IST are assessed using three approaches. First, to allow for robust policy conclusions, three different measures of income inequality are used (see also Finger and El Benni 2014a): (1) the Gini coefficient, (2) the Theil index, and (3) the 80/20 quintile share ratio (the ratio of the top and bottom $20 \%$ income percentile) $)^{9}$. To conduct pairwise comparisons among the IST specifications considered, non-parametric bootstrap $(N=1000)$ was used to derive confidence intervals for the inequality measures (Efron, 1993). These serve to test for significant differences among the inequality measures calculated for the different IST specifications by means of one-way ANOVA with the Scheffé-adjusted significance levels (Scheffé, 1959). Because results from these different income inequality measures yield similar results, in the text we only refer to the Gini coefficient. Results regarding the other measures are reported in the Appendix (Table 7).

Second, the consequences of IST are observed on two groups of farms: those that would have received and those that would not have received IST indemnifications based on their income development observed in the past.

The third approach used to assess the income distributional consequences of IST is the Gini decomposition by income source (Pyatt et al., 1980; Lerman and Yitzhaki, 1985; Keeney, 2000; Ciliberti and Frascarelli, 2018). When income is generated by $k$ components, the Gini coefficient can be decomposed as follows ${ }^{10}$ :

$$
G=\sum_{k=1}^{K} R_{K} * G_{K} * S_{K}
$$

$R_{k}$ denotes the "Gini correlation" between income component $k$ and the rank of total income. This is given by the covariance between income from the $k$-th income component and the rank of total income, divided by the covariance between income from this component and the rank of this same income component (Pyatt et al., 1980): $\operatorname{cov}\left(\mathrm{y}_{\mathrm{k}}, \mathrm{F}\right) /$ $\operatorname{cov}\left(\mathrm{y}_{\mathrm{k}}, \mathrm{F}_{\mathrm{k}}\right)$. Moreover, $G_{k}$ denotes the Gini coefficient for the $k$-th income component. Finally, $S_{k}$ denotes the income share of the $k$-th income source.

The product between $R_{k}$ and $G_{k}$ gives the concentration coefficient of the $k$-th income source $\left(C_{k}\right)$. It measures how income from each source is transferred across a

\footnotetext{
${ }^{9}$ The Gini coefficient measures twice the surface between the Lorenz curve (this maps the cumulative income share against the distribution of the population ranked from poorest to richest) and the line of equal distribution. It ranges from 0 (perfect equality) to 1 (perfect inequality). The Theil is a class of general entropy measure. We use the following formulation:T $=\frac{1}{N} \sum_{i=1}^{N} \frac{y_{i}}{\bar{y}} \ln \left(\frac{y_{i}}{\bar{y}}\right)$ where $N$ is the number of the individuals considered, $y_{i}$ is the income level of the $i$-th individual and $\bar{y}$ is the average income of such individuals. The values of this index vary between 0 and $\infty$, with zero representing an equal distribution and a higher value representing a higher level of inequality. The $80 / 20$ quintile share ratio is the ratio of the top and bottom $20 \%$ income percentile. It reveals how much richer the top $80 \%$ of the population is in comparison with the bottom $20 \%$ of the population. It ranges from 1 and $\infty$, with 1 representing an equal distribution and higher values representing a higher level of inequality. See Finger and El Benni (2014a) for further details.

${ }^{10}$ With a substantial incidence of negative incomes, $G(I)$ may become overstated, perhaps reaching values greater than 1 . However, the Gini decomposition procedure remains applicable if the average value of all income sources is positive for the entire sample (Pyatt et al., 1980; Findeis and Reddy, 1987).
} 
population that is ranked according to the level of total income received by each of its members.

Equation (6) shows that each income component influences income concentration depending on the importance of that source of income $\left(S_{k}\right)$, how it is distributed among the sample $\left(G_{k}\right)$, as well as the level of the "Gini correlation" between this income component and the rank of total income $\left(R_{k}\right)$ (Stark et al., 1986).

Pyatt et al. (1980) and Lerman and Yitzhaki (1985) developed a measure that partitions the overall inequality into contributing components. In the case of income, this allows an assessment of the "proportional contribution to inequality" of the $k$-th income source:

$$
P_{K}=\left(R_{K} * G_{K} * S_{K}\right) / G
$$

The marginal impact of a single income component on income inequality can be derived using the Gini coefficient rate of change with respect to the mean of $k$-th income component (Lerman and Yitzhaki, 1985):

$$
\frac{d G}{d \mu_{k}}=\frac{1}{\mu} *\left(C_{k}-G\right)
$$

in which $\mu_{k}$ is the mean value of the component $k$-th of income. This measure permits a comparison of the marginal contribution of each source of income to the inequality, even if these sources represent different shares of the overall income. In particular, we compare the Gini coefficient rate of change of direct payments with that of the net financial benefits generated by IST.

Finally, the Gini coefficient rate of change can be used to derive the elasticity of the Gini coefficient for each income component as follows:

$$
\eta_{k}=\frac{\mu_{k}}{G} * \frac{d G}{d_{\mu_{k}}}=\frac{1}{G} *\left[\frac{\mu_{k}}{\mu} *\left(C_{k}-G\right)\right]
$$

This measures the impact of a $1 \%$ change of a single income source on the income concentration, assuming that the internal ratio between the total income distribution and the mean of the income source is undisturbed (El Benni and Finger, 2013, p. 641).

The income of each farm with IST in place is subdivided into the three income sources referred to in (3): market income is calculated by subtracting direct payments from the observed income (MI); amount of direct payments (DP); net financial benefit of IST $\left(\mathrm{NB}_{\mathrm{IST}}\right)$. This last income component could assume different levels according to the different configurations of IST previously described. However, the Gini decomposition is developed solely based on the hypothesis that farmers pay a contribution proportional to their income (i.e., ContP as in (5)) ${ }^{11}$.

Non-overlapping confidence intervals are used to reject null hypotheses of no differences of marginal impacts across different income sources. Note that the use of $95 \%$ confidence intervals results in a much more conservative test than usual tests applied at the 5\% level of significance (see Payton et al. 2003 for numerical simulations).

\footnotetext{
${ }^{11}$ The Gini decomposition was also developed to consider additional costs that we refer to as transaction costs. These were assumed to be $20 \%$ of the IST contribution paid by the farmers to the Mutual Fund (Castañeda-Vera and Garrido 2017). The effect of transaction costs on income distribution is very limited (See Tables 10 and 11 in the Appendix).
} 


\section{Data}

We use the value added at the farm-level as underlying income variable for the analysis. This is obtained by deducting total intermediate consumption (farm-specific costs and overheads) from farm receipts (total output and public support) and measures the amount available for remuneration of the fixed production factors (work, land, and capital) (European Commission, 2010). The Italian Ministry of Agriculture has adopted farm value added as the income indicator to be used for IST (MIPAAF, 2017). Value added includes direct payments regardless of whether these are coupled to or decoupled from production.

The analysis is based on a balanced sample of farms which belonged to the Italian FADN $^{12}$ consecutively in the years from 2009 to $2015^{13}$. Data for the period 20092011 is used to identify farms' average income levels for 2012 according to (3). Thus, although data from 2009 onwards has been used, 2012 is the first year of simulated application of IST. Fourteen farms with negative average incomes in the considered years were removed from the analysis since negative incomes are usually treated differently in this type of insurance scheme (e.g., in the Canadian AgriStability program, Kimura and Anton, 2011, see also Finger and El Benni 2014a). This yields a balanced sample of 2777 farms, reflecting around 1/3 of the entire Italian FADN sample. While it is not possible to state that the sample fully represents the farming population ${ }^{14}$, the distribution of farms does include important components of this population with respect to geographical location of the farms (i.e., altimetry regions and macro-regions of Italy), farm size, and types of farming (Table 2$)^{15}$.

All monetary figures are deflated to allow comparability among data from different years by means of the Eurostat Harmonized Index of Consumer Prices (HICP) ${ }^{16}$.

\section{Results and discussion}

\section{Effects of IST on farm income stability, level, and inequality}

The main purpose of IST is to stabilize farm income. It reduces the level of variability in farm income over the investigated period by compensating farms which suffer severe

\footnotetext{
${ }^{12}$ FADN is a very commonly used database in policy analysis within the EU because, according to the European Commission (2010), it "is an instrument for evaluating the income of agricultural holdings and the impacts of the Common Agricultural Policy". It is generally biased towards commercial farms because very small farms are excluded from the survey. However, the sample also contains part-time farms ensuring the representation of several types of farming observed in the population.

${ }^{13} \mathrm{CAP}$ reform was introduced in 2015 . Hence, from a concept point of view, this year differs from previous years in terms of direct payment policy. However, the changes introduced in 2015 were not massive in Italy as the chosen methods of gradual and partial convergence maintain the overall amount of direct payments received by each farm very close to the amount received in the previous period (European Commission, 2015). However, to account for the peculiarity of 2015, results from this year have been compared with those from previous years. Results related to income concentration and the Gini decomposition show that the confidence intervals referring to 2015 overlap with those referring to all previous years. Similarly, results for the whole 2012-15 period do not differ from those referring only to the 2012-14 period (Tables 8 and 9 in the Appendix).

${ }^{14}$ The selection of a constant sample may result in a sample bias. However, a constant sample is needed because the analysis of the variability of farm income must be based on data referring to a relatively long period of time

${ }^{15}$ Basic statistics of the farm sample are reported in the Appendix, Table 6.

${ }^{16}$ Available at: http://ec.europa.eu/eurostat/web/hicp/data/database.
} 
Table 2 Number of the sampled farms and their distribution among altimetry regions, types of farming, farm size, and macro-regions of Italy. Balanced sample (year 2015)

\begin{tabular}{|c|c|c|}
\hline & No. of obs.s & Freq. \\
\hline All observations & 2777 & $100 \%$ \\
\hline \multicolumn{3}{|l|}{ Altimetry regions } \\
\hline Mountain & 622 & $22 \%$ \\
\hline Hill & 1210 & $44 \%$ \\
\hline Plain & 945 & $34 \%$ \\
\hline \multicolumn{3}{|l|}{ Types of farming (TF) } \\
\hline Spec.ed fieldcrops & 680 & $24 \%$ \\
\hline Spec.ed horticulture & 230 & $8 \%$ \\
\hline Spec.ed permanent crops & 828 & $30 \%$ \\
\hline Spec.ed grazing livestock & 609 & $22 \%$ \\
\hline Spec.ed granivore livestock & 77 & $3 \%$ \\
\hline Mixed crops & 177 & $6 \%$ \\
\hline Mixed livestock, crops and livestock & 176 & $6 \%$ \\
\hline \multicolumn{3}{|l|}{ Farm size^ } \\
\hline Small & 651 & $23 \%$ \\
\hline Medium-small & 674 & $24 \%$ \\
\hline Medium & 631 & $23 \%$ \\
\hline Medium-large & 699 & $25 \%$ \\
\hline Large & 122 & $4 \%$ \\
\hline \multicolumn{3}{|l|}{ Macro-regions (MR) } \\
\hline Center & 362 & $13 \%$ \\
\hline Islands & 168 & $6 \%$ \\
\hline South & 594 & $21 \%$ \\
\hline North-west & 954 & $34 \%$ \\
\hline North-east & 699 & $25 \%$ \\
\hline
\end{tabular}

$\wedge$ According to economic standard output classes (European Commission, 2010)

Source: Own elaborations on Italian FADN data

drops in their incomes. This is underlined if comparing results referring to the current situation (i.e., without the IST) with those resulting from the scenarios in which the IST is introduced (Table 1) (Fig. 1) ${ }^{17}$.

IST is highly effective in stabilizing farm income and this is the case even if the level of direct payments is reduced (Fig. 1). As expected, these are also found to play a role in income stabilization since reductions in direct payment levels result in an increase in relative income variability.

Since IST is subsidized, it enhances the average income level of the farming population. On average, the income level with IST is higher than without this tool in place. This is shown in Fig. 2 where the line referring to the average income level with IST

\footnotetext{
${ }^{17}$ Results regarding the scenarios $I I$ and IIF are not included in the following Figures for the sake of clarity. Scenario II is ruled out by the EU Regulation. Scenario IIF does not seem appropriate given the large heterogeneity of farm size in Italy.
} 


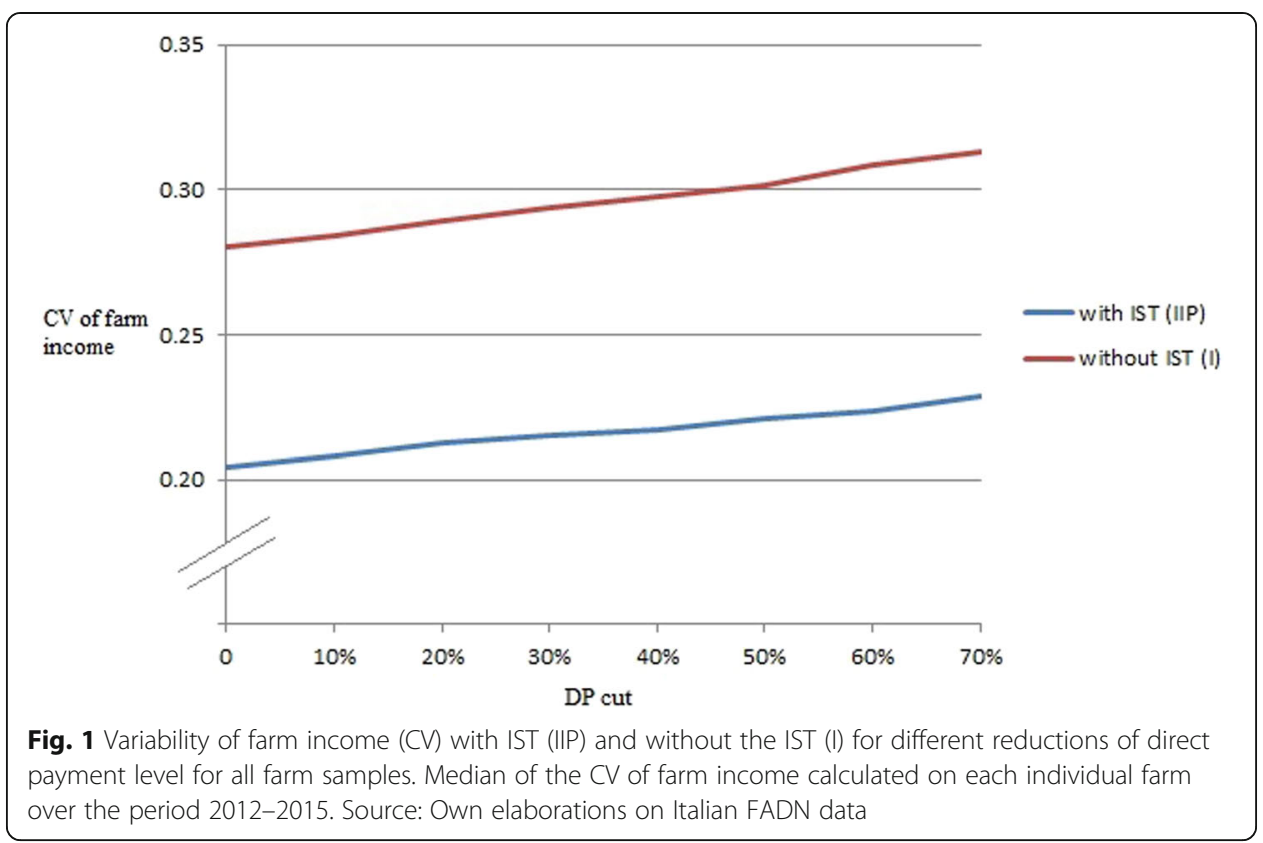

(scenario IIP) is above that referring to the baseline condition (scenario $I$ ) for any level of direct payments $(x \text {-axis })^{18}$. Farm income levels decline as direct payments decrease (i.e., moving right on the $x$-axis of Fig. 2). These results show that the incomeenhancing role of IST can partially compensate for the income loss caused by possible cuts in direct payments (Fig. 2). Finally, note that the financial resources distributed by IST will only increase to a very negligible extent when simulating direct payment reductions. This is shown by the fact that the two curves in Fig. 2 remain more or less at the same distance regardless the level of cut in direct payments.

The IST causes a re-distribution of resources within the farming population that can lead to a reduction in income inequality. Note that there is a marked difference between how support is distributed by means of IST and direct payments: while the latter are granted to almost all farms, the IST is targeted to support only those farms experiencing large income drops. These differences can be seen graphically by considering two groups of farms: farms that are indemnified (ind) and those that are not (no ind). The income gap between these two groups of farms is very large when IST is not in place ( $I$ (ind) $<I$ (no ind)) (Fig. 3). This gap is reduced significantly when IST is applied (Fig. 3).

About $20 \%$ of the farms in the sample are expected to receive an indemnification each year. Over the entire 4-year period (i.e., 2012-2015), we observe that $60 \%$ of the sampled farms receive an indemnity at least once. Assuming that $65 \%$ of the indemnifications is covered by subsidies from public funds, IST increases the average income of these farms by $6 \%$. This small relative increase is in line with the

\footnotetext{
${ }^{18}$ Transaction costs linked to participation in IST do not seem to change this result. The income enhancing effect of IST could only be reversed in the very unlikely case in which TC exceed the $220 \%$ of the IST contribution (Table 10 in the Appendix).
} 


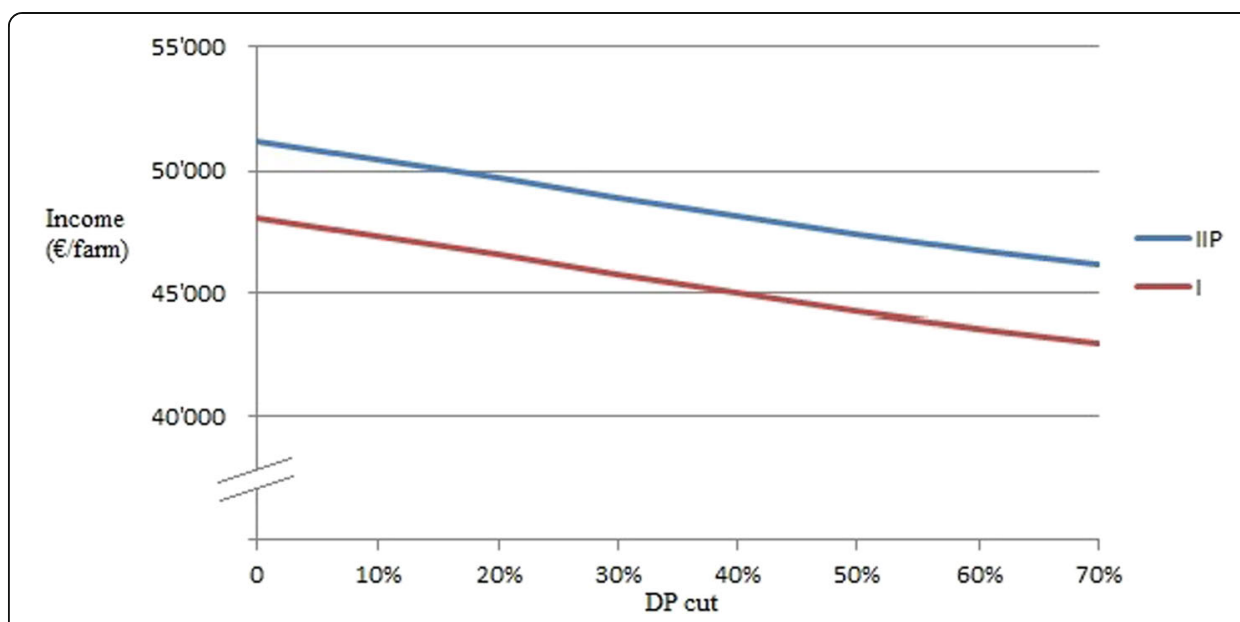

Fig. 2 Farm income level with (IIP) and without the IST in place (I), for different reductions of direct payments level. All farm samples, average of the period 2012-2015 (Euro/farm). Source: Own elaborations on Italian FADN data

fact that the policy support provided by IST is limited when compared to both the overall income and to the amount of direct payments currently received. Indeed, IST accounts for just one fourth of the overall support provided by both policy measures.

As expected, on average, farms receiving indemnifications have a lower income level than other farms (Fig. 3). This is important because it is one of the reasons explaining the income concentration-reducing effect of IST.

Since every farm must pay a contribution to the mutual fund managing the IST and only part of this is covered by policy support, the average income of farms that do not

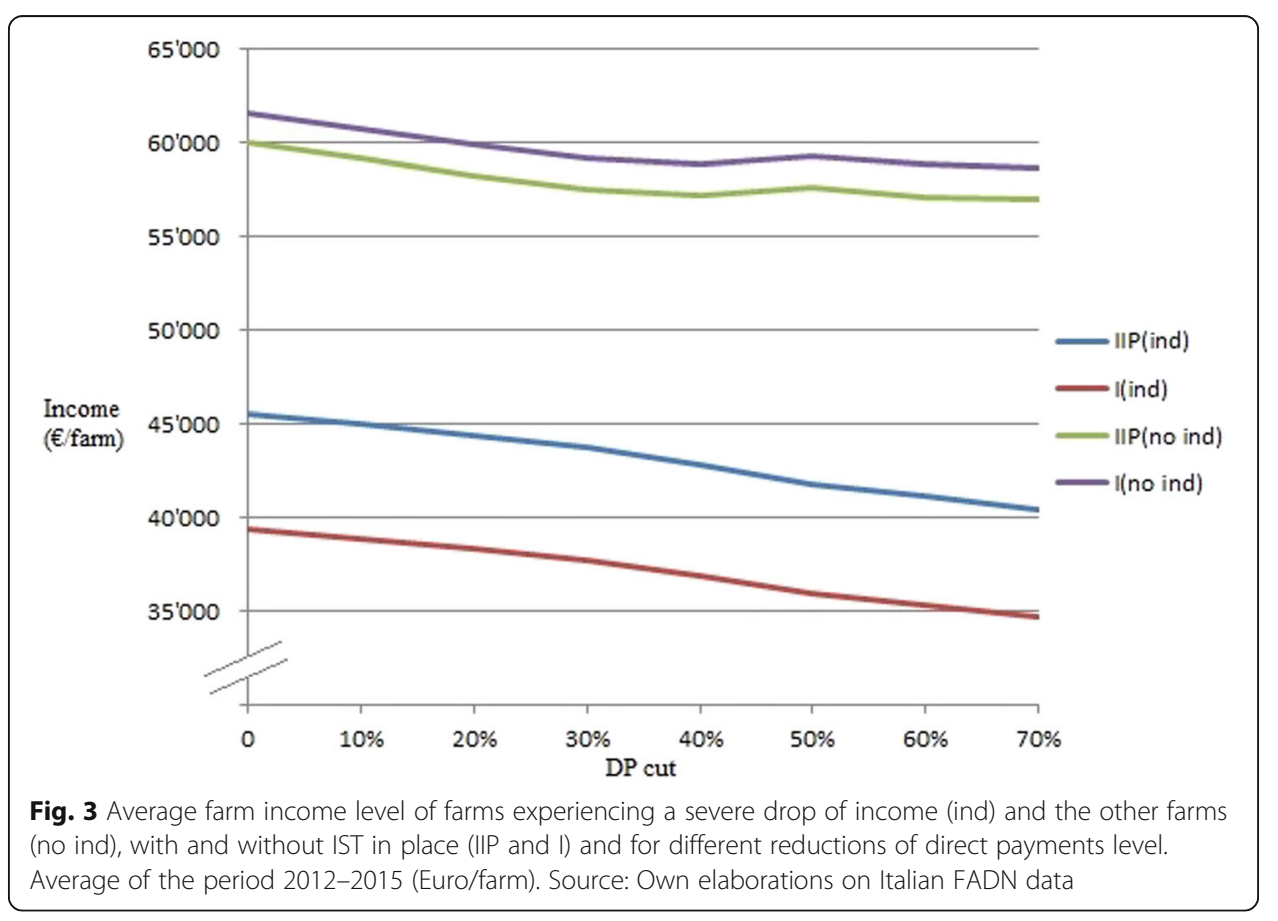


Table 3 Effects of the IST on farm income concentration. Gini coefficient without and with the simulated implementation of the IST. Years from 2012 to 2015 and whole period

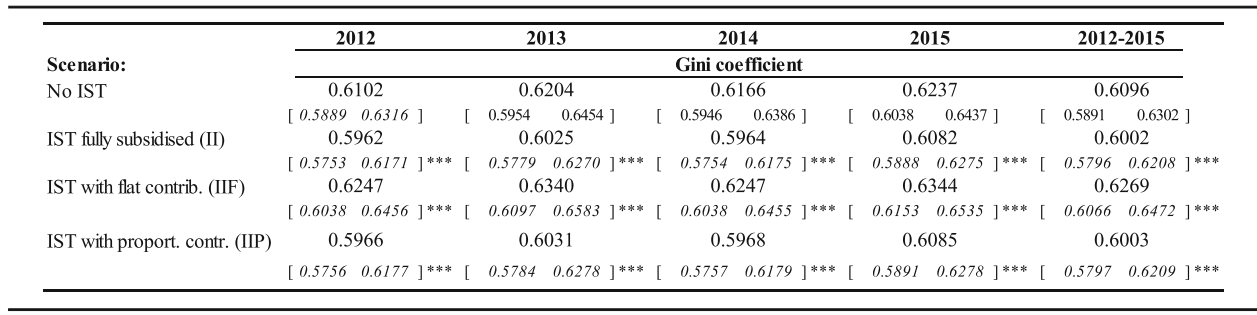

Note: Numbers in brackets depict $95 \%$ confidence intervals

***Difference to the "no insurance" scenario (No IST) is significant at the $1 \%$ level

Source: Own elaborations on Italian FADN data

receive indemnifications declines in comparison with the No-IST situation (i.e., I(no ind) $<I I P$ (no ind)). However, the income of these farms does not decline very much (Fig. 3) because the overall cost of the indemnifications is spread over a relatively large number of farms. In contrast, indemnified farms benefit significantly from IST: here, the income-enhancing role of IST is relevant $(I I P($ ind $)>I($ ind $)$ ) (Fig. 3).

IST reduces significantly income inequality apart from the case in which farmers are required to pay a flat rate contribution to the mutual fund (i.e., each farm pays the same amount) (scenario IIF). Table 3 reports the Gini coefficients calculated without the IST (baseline) and under the three scenarios of IST application: IST fully subsidized and IST with flat rate contribution and with proportional contribution (Table 1).

Concentration declines when indemnification costs are subsidized fully by the government and when farms pay proportional contributions. On the other hand, concentration increases in the flat rate case (Table 3). This happens in almost all considered years. According to the ANOVA results, the concentration always differs statistically (at 1\% significance level) with the IST in place when compared with the "No IST" case (Table 3) ${ }^{19}$.

If farmers are asked to pay contributions that are proportional to their income level, the effect of IST in terms of reducing income concentration is very similar to that which occurs when it is fully subsidized (Table 3$)^{20}$. On the other hand, in all but two cases the application of IST with a flat rate contribution causes a significant increase in income inequality in all considered periods (Table 3 ).

\section{Contribution of direct payments and IST to income equality: results of the Gini decomposition}

The Gini decomposition analysis focuses on the case in which farmers pay a contribution that is proportional to their expected incomes because it is the most likely scenario for its application ${ }^{21}$. The three considered income sources generate very different shares of the overall farm income. On average, market income accounts for around

\footnotetext{
${ }^{19}$ Results for the Theil indexes and the 80/20 ratios confirm this finding (Table 7 in the Appendix).

${ }^{20}$ ANOVA results do not allow rejection of the null hypothesis (i.e. concentration levels do not differ between IST scenarios) at the $5 \%$ level of significance.

${ }^{21}$ See foot-note $q$ for the reasons motivating this choice
} 
Table 4 Gini decomposition by income sources. All farm sample, years from 2012 to 2015 and whole period

\begin{tabular}{|c|c|c|c|c|c|}
\hline & Share & $\begin{array}{c}\text { Gini } \\
\text { coefficient }\end{array}$ & $\begin{array}{c}\text { Gini } \\
\text { correlation }\end{array}$ & $\begin{array}{l}\text { Proportional } \\
\text { contribution }\end{array}$ & Elasticity \\
\hline & $S_{k}$ & $\mathrm{G}_{\mathrm{k}}$ & $\mathrm{R}_{\mathrm{k}}$ & $\mathrm{P}_{\mathrm{k}}$ & $\eta_{\mathrm{k}}$ \\
\hline & \multicolumn{5}{|c|}{2012} \\
\hline Market Income (MI) & 0.794 & 0.641 & 0.962 & 0.821 & 0.026 \\
\hline Direct Payments (DP) & 0.149 & 0.722 & 0.721 & 0.130 & -0.019 \\
\hline $\begin{array}{l}\text { Net financial Benefits from } \\
\text { IST }\left(\mathrm{NB}_{\mathrm{IST}}\right)^{\wedge}\end{array}$ & 0.056 & 1.461 & 0.356 & 0.049 & -0.007 \\
\hline \multirow[t]{2}{*}{ Farm income (IIP) } & & 0.597 & & & \\
\hline & \multicolumn{5}{|c|}{2013} \\
\hline Market Income (MI) & 0.795 & 0.665 & 0.948 & 0.832 & 0.037 \\
\hline Direct Payments (DP) & 0.148 & 0.726 & 0.723 & 0.129 & -0.019 \\
\hline $\begin{array}{l}\text { Net financial Benefits from } \\
\text { IST }\left(\mathrm{NB}_{\mathrm{IST}}\right)^{\wedge}\end{array}$ & 0.056 & 1.511 & 0.277 & 0.039 & -0.017 \\
\hline \multirow[t]{2}{*}{ Farm income (IIP) } & \multirow{2}{*}{\multicolumn{5}{|c|}{0.603}} \\
\hline & & & & & \\
\hline Market Income (MI) & 0.785 & 0.657 & 0.951 & 0.822 & 0.037 \\
\hline Direct Payments (DP) & 0.150 & 0.729 & 0.721 & 0.132 & -0.018 \\
\hline $\begin{array}{l}\text { Net financial Benefits from } \\
\text { IST }\left(\mathrm{NB}_{I S T}\right)^{\wedge}\end{array}$ & 0.065 & 1.418 & 0.299 & 0.047 & -0.019 \\
\hline \multirow[t]{2}{*}{ Farm income (IIP) } & \multirow{2}{*}{\multicolumn{5}{|c|}{2015}} \\
\hline & & & & & \\
\hline Market Income (MI) & 0.786 & 0.675 & 0.945 & 0.824 & 0.038 \\
\hline Direct Payments (DP) & 0.150 & 0.736 & 0.715 & 0.130 & -0.020 \\
\hline $\begin{array}{l}\text { Net financial Benefits from } \\
\text { IST }\left(\mathrm{NB}_{\mathrm{IST}}\right)^{\wedge}\end{array}$ & 0.064 & 1.459 & 0.304 & 0.047 & -0.017 \\
\hline \multirow[t]{2}{*}{ Farm income (IIP) } & \multirow{2}{*}{\multicolumn{5}{|c|}{ 2012-2015 }} \\
\hline & & & & & \\
\hline Market Income (MI) & 0.788 & 0.636 & 0.975 & 0.814 & 0.026 \\
\hline Direct Payments (DP) & 0.150 & 0.723 & 0.742 & 0.134 & -0.016 \\
\hline $\begin{array}{l}\text { Net financial Benefits from } \\
\text { IST }\left(\mathrm{NB}_{\mathrm{IST}}\right)^{\wedge}\end{array}$ & 0.061 & 1.120 & 0.451 & 0.052 & -0.010 \\
\hline Farm income (IIP) & & 0.600 & & & \\
\hline
\end{tabular}

$\wedge$ Assuming that farmers pay contributions proportional to their income to cover $35 \%$ of the overall indemnification cost (scenario IIP)

Source: Own elaborations on Italian FADN data

$79 \%$ of the farm income, direct payments around $15 \%$ and the net financial benefits of IST 6\% (Table 4).

As reported by previous analyses, direct payments are relatively more concentrated than market incomes (Gini coefficient $G_{k}$ in Table 4) (Severini et al., 2014a and b).

We find that the net financial benefits of IST are extraordinarily concentrated because of the nature of this tool: it provides indemnifications only to a limited share of the farms each year. In all considered years, the Gini coefficient is higher than unity because the majority of the farms have a negative net financial benefit from the application of IST since they pay contributions without receiving any indemnification. However, when the 4 years reviewed are considered together, there is a marked decline in the number of farms with a negative average net benefit from IST in comparison with the single year cases. Therefore, the concentration of this income source calculated over the whole 4-year period (bottom panel of Table 4) is lower than when calculated on a single year basis. 
Table 5 Gini decomposition under the scenario of implementation of IST with a contribution proportional to farm income (Scenario IIP). Levels and confidence intervals $\wedge$ of marginal impact $\wedge$ by income source. Years from 2012 to 2015 and whole period

\begin{tabular}{|c|c|c|c|c|c|}
\hline \multirow{4}{*}{ MI } & 2012 & 2013 & 2014 & 2015 & 2012-2015 \\
\hline & \multicolumn{5}{|c|}{ Marginal Impact^^ } \\
\hline & 0.000432 & 0.000634 & 0.000602 & 0.000588 & 0.000096 \\
\hline & {$\left[\begin{array}{ll}0.000275 & 0.000589\end{array}\right]$} & {$\left[\begin{array}{ll}0.000433 & 0.000835\end{array}\right]$} & {$\left[\begin{array}{ll}0.000441 & 0.000762\end{array}\right]$} & {$\left[\begin{array}{ll}0.000421 & 0.000755\end{array}\right]$} & {$\left[\begin{array}{ll}0.000062 & 0.000130\end{array}\right]$} \\
\hline \multirow[t]{2}{*}{ DP } & -0.001667 & -0.001797 & -0.001533 & -0.001667 & -0.000314 \\
\hline & $-0.001097]$ & {$\left[\begin{array}{ll}-0.002537 & -0.001058\end{array}\right]$} & {$[-0.002127$} & {$[-0.002261]$} & {$\left[\begin{array}{cc}-0.000454 & -0.000175\end{array}\right]$} \\
\hline \multirow[t]{2}{*}{$\mathrm{NB}_{\mathrm{IST}}$} & -0.001676 & -0.004215 & -0.003716 & -0.003330 & -0.000464 \\
\hline & {$[-0,003594$} & {$\left[\begin{array}{ll}-0.007437 & -0.000993\end{array}\right]$} & {$[-0.005766$} & {$[-0.005271$} & {$[-0.000876$} \\
\hline
\end{tabular}

The income concentration-reducing role of IST is driven by a small Gini correlation $\left(R_{k}\right)$ (Table 4). This means that the financial benefits from IST are not distributed in favor of high-income farms, given that this income component is only correlated very weakly with the rank of the overall farm income. It is important to note that the net financial benefits from the application of IST have an even lower Gini correlation than direct payments (i.e., around half that of direct payments).

Based on these latter results, the proportional contribution of the net benefits from the IST to the overall income concentration $\left(P_{k}\right)$ is lower than its share $\left(S_{k}\right)$ (Table 4). A similar situation is found for direct payments while the opposite is true for market income.

IST reduces income concentration as shown by the negative elasticity of the financial benefits it provides. In accordance with the results of El Benni and Finger (2014a), the proportional contribution to income concentration (i.e., $P_{k}$ ) of the income generated by IST is substantially lower than that of the other two income components (Table 4). However, this result is strongly influenced by the fact that the share of the income derived by IST is far less relevant than that of the other income components.

Therefore, to facilitate the comparison, we also derive the marginal contribution of each source of income. This permits a comparison of their effects on income inequality even if these sources represent different shares of the overall income. The marginal impact of IST is significantly different from zero according to Wilcoxon rank sum tests and more negative than that of direct payments (Table 5). This suggests that IST could indeed play a significant role in reducing income concentration ${ }^{22}$.

While the extent of the marginal impact of the IST benefits exceeds that of direct payments, the obtained confidence intervals often overlap. Hence, it is not possible to reject the hypothesis of differences of marginal impact of IST from that of direct payments (Table 5).

The analysis has shown that direct payments and IST have a similar income concentration-reducing effect at the margin under the current conditions. However, this may not necessarily be the case when considering a level of direct payments that differs from the one currently in force. To analyze this issue, we first simulate a linear

\footnotetext{
${ }^{22}$ The results of the Gini decomposition do not change significantly when considering transaction costs equal to $20 \%$ of the IST contribution paid (Table 11 in the Appendix).
} 


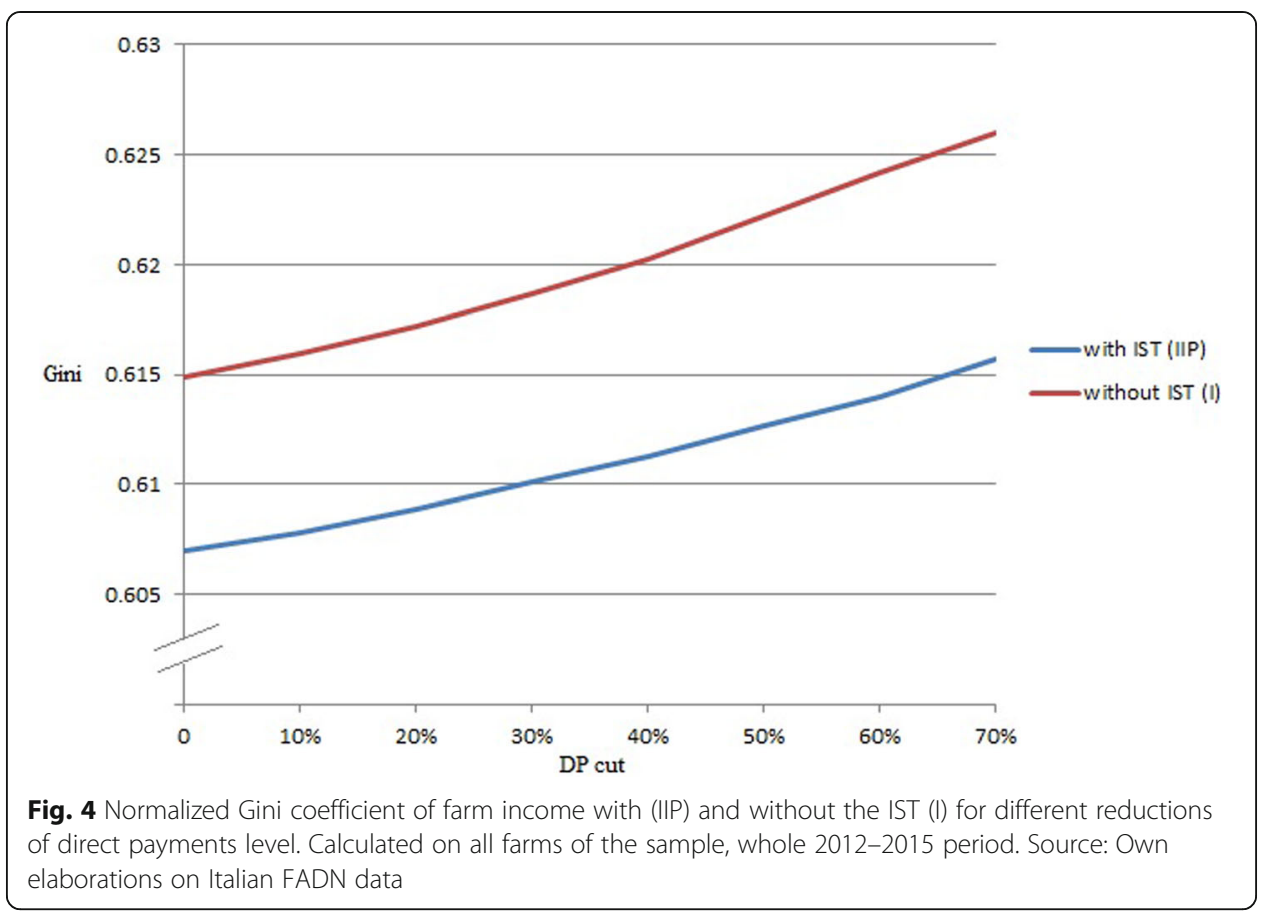

relative cut of direct payment levels and, subsequently, we assess the impact of the application of IST on income concentration. This simulation is performed only under the assumption that farmers' contribution to the mutual fund is proportional to their average income (scenario IIP). As expected, cutting direct payments causes the income concentration to increase even with the IST in place. Furthermore, the reduction of the normalized Gini coefficient (Chen et al., 1982) caused by IST has roughly the same magnitude for all considered levels of direct payments (Fig. 4). However, under the simulated conditions, IST does partially counteract the effect of cutting direct payments regarding income concentration.

To summarize, results clearly show that IST can reduce income inequality if farmers pay a contribution that is proportional to their income. In contrast, a flat rate contribution increases income inequality, a finding that contrasts with those of Finger and El Benni (2014a) for Swiss agriculture ${ }^{23}$

\section{Conclusions}

In this paper, we provide a multidimensional assessment of the IST by evaluating the possible implications of its implementation in terms of income stabilization,

\footnotetext{
${ }^{23}$ This is probably because of three main reasons. First, the income concentration observed in the baseline case (without IST) is substantially higher in Italy than in Switzerland because the farming population in Italy is very heterogeneous in terms of farm size. According to the 2013 Farm Structural Survey, while the average farm size is around 12 ha of Utilized Agricultural Area, 58\% of the Italian farms are smaller than 5 ha while $8 \%$ are larger than 30 ha (Eurostat, 2013). Second, the application of IST with the flat rate approach (i.e. as used by Finger and El Benni (2014a)) has a negative impact on the income of the many small Italian farms while favoring large farms. Third, the relative reduction of the concentration due to the fully subsidized IST scenario is smaller in Italy than that reported by Finger and El Benni (2014a).
} 
income levels, and income distribution using the example of Italian agriculture. The analysis also addresses the issue of the interdependencies between IST and CAP direct payments by simulating, on an ex ante basis, the implementation of IST under reduced levels of direct payments. We apply the Gini decomposition by income sources, including both direct payments and the net financial benefits derived from IST, to compare the income concentration effects of both policies.

Our results confirm that IST could stabilize farm income significantly. Furthermore, our results reveal two additional aspects that seem important from a policy point of view. Firstly, IST increases the average farm income due to the governmental support it provides. However, the extent of this increase is moderate and does not suffice to compensate for large reductions in the level of direct payments. Clearly, it is possible that modifications in policy design (e.g., reductions of trigger level and increases of compensation rate) could alter these results. Secondly, the analysis confirms the findings of Finger and El Benni (2014a) that IST could reduce income inequality among the farming population. However, the analysis adds to the current debate by showing that the extent of the income concentration reduction effects of both direct payments and IST has the same sign and similar magnitude at the margin. More specifically, both contribute to reductions of income inequality in the farming population.

The analysis has shown that direct payments and IST are expected to interact since they have similar effects on the three considered dimensions of farm income. First, the results of the analysis suggest that in its current form, IST could provide an amount of income support that partially offset cuts in direct payments that may result from the current debate on the Multiannual Financial Framework for the period 2021-2027 (European Commission, 2018; Matthews, 2018). Second, a reduction of direct payments would only cause a negligible increase in the amount of indemnifications that farmers receive from IST. This is in contrast with the hypothesis that IST will gain importance if direct payments levels are reduced.

The analysis does have some limitations that must be kept in mind when seeking to interpret the results correctly and draw sound policy conclusions. It does not apply behavioral models and therefore does not allow for the possible effect of IST on farmers' production choices. The setting of the analysis suggests that its findings focus on the short run effects of IST and refer to a situation where all farmers participate. Future analyses will be needed to assess possible effects of IST on farmers' behavior, especially with respect to changes in production and risk management decisions as well as with respect to participation in such a scheme.

Allowing for the limitations of the analysis, the results do permit some policy conclusions that could support the design and implementation of IST. The main one is that the opportunity to implement IST should be evaluated not only with respect to its income-stabilizing effects, but also from the angle of two additional positive effects that have not yet been included in the policy debate: its ability to enhance farm income and to reduce income inequality among the farm population. Finally, the results of the analysis seem useful for the design of IST, especially in the case of Italian agriculture: contributions proportional to farm income are to be preferred since this is more effective in terms of income concentration reduction than defining a flat rate contribution. 


\section{Appendix}

Table 6 Average farm size in terms of farm income (Euro/farm) and utilized agricultural area (ha/ farm) in the sampled farms. Whole sample, and farms grouped by: altimetry regions, types of farming, farm size, and macro-regions of Italy. Balanced sample (year 2015). Mean values and coefficients of variation (CV) within the groups.

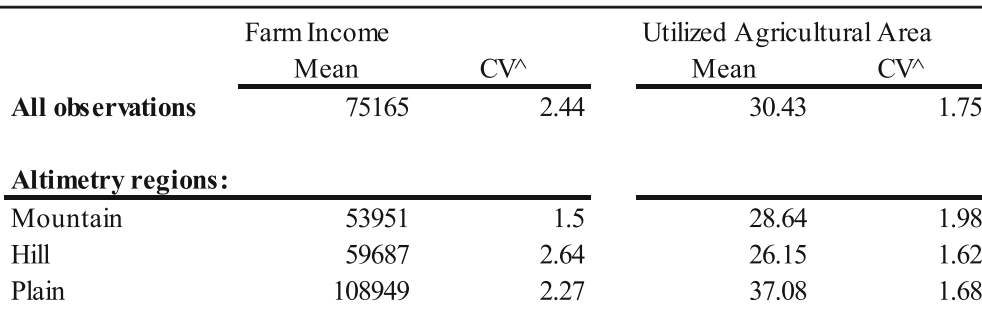

Types of farming (TF):

\begin{tabular}{|c|c|c|c|c|}
\hline & \\
\hline Spec.ed fieldcrops & 64006 & 2.64 & 43.95 & 1.21 \\
\hline Spec.ed horticulture & 79152 & 1.88 & 3.42 & 1.86 \\
\hline Spec.ed permanent crops & 68094 & 2.71 & 12.76 & 1.61 \\
\hline Spec.ed grazing livestock & 94085 & 2.3 & 47.88 & 1.57 \\
\hline Spec.ed granivore livestock1 & 163032 & 1.82 & 22.34 & 1.17 \\
\hline Mixed crops & 47637 & 2 & 27.95 & 1.83 \\
\hline $\begin{array}{l}\text { Mixed livestock, } \\
\text { crops and } \\
\text { livestock }\end{array}$ & 70121 & 1.87 & 42.18 & 1.68 \\
\hline \multicolumn{5}{|l|}{ Farm size ${ }^{\wedge} \wedge:$} \\
\hline Small & 14403 & 0.96 & 9.67 & 0.89 \\
\hline Medium-small & 28505 & 0.89 & 15.04 & 0.99 \\
\hline Medium & 50347 & 0.71 & 25.86 & 1.06 \\
\hline Medium-large & 130808 & 1.01 & 55.61 & 1.12 \\
\hline Large & 466737 & 1.44 & 105.46 & 1.48 \\
\hline \multicolumn{5}{|l|}{ Macro-regions (MIR): } \\
\hline Center & 54421 & 1.75 & 31.59 & 1.25 \\
\hline Islands & 80894 & 4.02 & 41.92 & 1.11 \\
\hline South & 53913 & 1.77 & 30.56 & 1.78 \\
\hline North-West & 86464 & 2.37 & 32.97 & 1.86 \\
\hline North-East & 87171 & 2.24 & 23.47 & 2.01 \\
\hline
\end{tabular}

$\wedge$ Coefficient of variation

$\wedge \wedge$ According to economic standard output classes (European Commission, 2010) Source: Own elaborations on Italian FADN data 
Table 7 Effects of the IST on farm income concentration. Theil and 80/20 ratio. Years from 2012 to 2015 and whole period

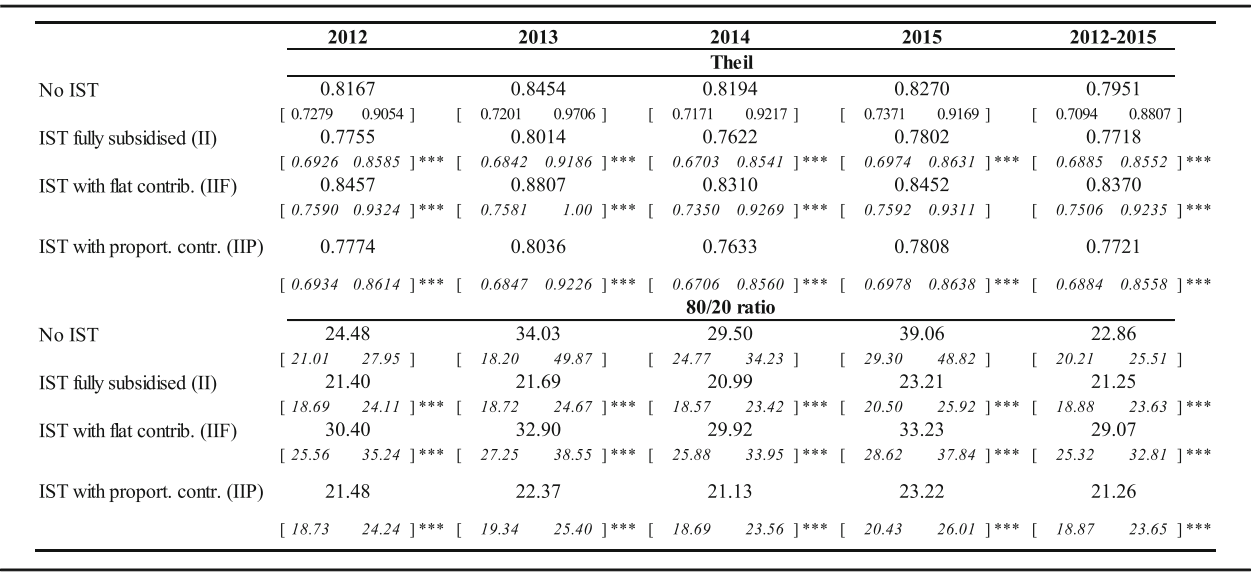

Note: Numbers in brackets depict $95 \%$ confidence intervals

***Difference to the "no insurance" scenario (No IST) is significant at the $1 \%$ level

Source: Own elaborations on Italian FADN data

Table 8 Gini decomposition by income sources whole period 2012-2014

\begin{tabular}{lccccc}
\hline & Share & $\begin{array}{c}\text { Gini } \\
\text { coefficient }\end{array}$ & $\begin{array}{c}\text { Gini } \\
\text { correlation }\end{array}$ & $\begin{array}{c}\text { Proportional } \\
\text { contribution }\end{array}$ & Elasticity \\
& $\mathrm{S}_{\mathrm{k}}$ & $\mathrm{G}_{\mathrm{k}}$ & $\mathrm{R}_{\mathrm{k}}$ & $\mathrm{P}_{\mathrm{k}}$ & $\eta_{\mathrm{k}}$ \\
\cline { 2 - 6 } & & & $\mathbf{2 0 1 2 - 2 0 1 4}$ & & 0.028 \\
Market Income (MI) & 0.796 & 0.628 & 0.973 & 0.825 & -0.018 \\
Direct Payments (DP) & 0.145 & 0.718 & 0.722 & 0.127 & -0.011 \\
Net financial Benefits from IST & 0.059 & 1.224 & 0.396 & 0.049 & \\
(NB $\left._{\text {IST }}\right)^{\wedge}$ & & 0.590 & & & \\
Farm income (IIP) & & &
\end{tabular}

IImpact of an increase of 1000 Euro/farm

$\wedge \wedge$ Assuming that farmers pay contributions proportional to their income to cover $35 \%$ of the overall indemnification cost (IIP)

Source: Own elaborations on Italian FADN data

Table 9 Gini decomposition. Marginal Impact by income source derived from the bootstrap procedure in the whole period 2012-2014^

\begin{tabular}{|c|c|c|c|}
\hline \multirow{4}{*}{ MI } & \multicolumn{2}{|c|}{ 2012-2014 } & \\
\hline & \multicolumn{3}{|c|}{ Marginal Impact ${ }^{\wedge} \wedge$} \\
\hline & \multicolumn{3}{|c|}{0.000143} \\
\hline & {$[0.000101$} & 0.000186 & ] $* * *$ \\
\hline \multirow[t]{2}{*}{$\mathrm{DP}$} & \multicolumn{3}{|c|}{-0.000492} \\
\hline & [ -0.000684 & -0.000301 & ] $* * *$ \\
\hline \multirow[t]{2}{*}{$\mathrm{NB}_{\text {IST }}$} & \multicolumn{3}{|c|}{-0.000729} \\
\hline & {$[-0.001265$} & -0.000193 & ] $* * *$ \\
\hline
\end{tabular}

$\wedge 95 \%$ confidence intervals reported in brackets

$\wedge \wedge$ Marginal impact expressed as impact of an increase of 1000 Euro/farm

***Different from zero at $1 \%$ significance

$M I$ market income, $D P$ direct payments, $N B_{I S T}$ net benefits from IST under the hypothesis of proportional contributions

Source: Own elaborations on Italian FADN data 
Table 10 Average annual farm income levels in the whole 2012-2015 period with application of growing levels of transaction costs. Farmers contribution to the mutual fund proportional to their incomes (scenario IIP)

\begin{tabular}{|c|c|c|c|c|c|c|c|c|c|}
\hline & \multicolumn{9}{|c|}{ Transaction cost as share of farmers' contribution to Mutual Fund: } \\
\hline & $0 \%$ & $20 \%$ & $35 \%$ & $50 \%$ & $80 \%$ & $100 \%$ & $150 \%$ & $200 \%$ & $220 \%$ \\
\hline \multicolumn{10}{|l|}{ Scenario: } \\
\hline IST with proport. contr. (IIP) & 51,223 & 50,938 & 50,724 & 50,511 & 50,084 & 49,799 & 49,087 & 48,376 & 48,091 \\
\hline
\end{tabular}

Source: Own elaborations on Italian FADN data

Table 11 Gini decomposition by income sources with transaction cost. All farm sample, years from 2012 to 2015, and whole periods 2012-2015 and 2012-2014. Transaction costs set at 20\% of the contribution

\begin{tabular}{|c|c|c|c|c|c|c|}
\hline & Share & $\begin{array}{c}\text { Gini } \\
\text { coefficient }\end{array}$ & $\begin{array}{c}\text { Gini } \\
\text { correlation }\end{array}$ & $\begin{array}{l}\text { Proportional } \\
\text { contribution }\end{array}$ & Elasticity & $\begin{array}{c}\text { Marginal } \\
\text { Impact }^{\wedge}\end{array}$ \\
\hline & $S_{k}$ & $\mathrm{G}_{\mathrm{k}}$ & $\mathrm{R}_{\mathrm{k}}$ & $\mathrm{P}_{\mathrm{k}}$ & $\eta_{\mathrm{k}}$ & $\mathrm{dG} / \mathrm{d} \mu_{\mathrm{k}}$ \\
\hline & \multicolumn{6}{|c|}{2012} \\
\hline Market Income (MI) & 0.799 & 0.641 & 0.962 & 0.825 & 0.026 & 0.000433 \\
\hline Direct Payments (DP) & 0.150 & 0.722 & 0.721 & 0.131 & -0.019 & -0.001678 \\
\hline $\begin{array}{l}\text { Net financial Benefits from } \\
\text { IST }\left(\mathrm{NB}_{\mathrm{IST}}\right)^{\wedge \wedge}\end{array}$ & 0.052 & 1.637 & 0.314 & 0.044 & -0.007 & -0.001832 \\
\hline \multirow[t]{2}{*}{ Farm income (IIP) } & \multicolumn{6}{|c|}{0.597} \\
\hline & & & & 2013 & & \\
\hline Market Income (MI) & 0.800 & 0.665 & 0.948 & 0.837 & 0.037 & 0.000636 \\
\hline Direct Payments (DP) & 0.149 & 0.726 & 0.723 & 0.130 & -0.020 & -0.001813 \\
\hline $\begin{array}{l}\text { Net financial Benefits from } \\
\text { IST }\left(\mathrm{NB}_{\mathrm{IST}}\right)^{\wedge \wedge}\end{array}$ & 0.051 & 1.717 & 0.233 & 0.034 & -0.017 & -0.004673 \\
\hline \multirow[t]{2}{*}{ Farm income (IIP) } & \multicolumn{6}{|c|}{0.603} \\
\hline & & & & 2014 & & \\
\hline Market Income (MI) & 0.790 & 0.657 & 0.951 & 0.827 & 0.037 & 0.000605 \\
\hline Direct Payments (DP) & 0.150 & 0.729 & 0.721 & 0.132 & -0.018 & -0.001546 \\
\hline $\begin{array}{l}\text { Net financial Benefits from } \\
\text { IST }\left(\mathrm{NB}_{\mathrm{IST}}\right)^{\wedge \wedge}\end{array}$ & 0.060 & 1.585 & 0.258 & 0.041 & -0.019 & -0.004090 \\
\hline \multirow[t]{2}{*}{ Farm income (IIP) } & & 0.597 & & & & \\
\hline & \multicolumn{6}{|c|}{2015} \\
\hline Market Income (MI) & 0.791 & 0.675 & 0.946 & 0.829 & 0.038 & 0.000592 \\
\hline Direct Payments (DP) & 0.151 & 0.736 & 0.715 & 0.130 & -0.021 & -0.001680 \\
\hline $\begin{array}{l}\text { Net financial Benefits from } \\
\text { IST }\left(\mathrm{NB}_{\mathrm{IST}}\right)^{\wedge \wedge}\end{array}$ & 0.058 & 1.634 & 0.262 & 0.041 & -0.017 & -0.003687 \\
\hline \multirow[t]{2}{*}{ Farm income $(I I P)$} & \multirow{2}{*}{\multicolumn{6}{|c|}{ 2012-2015 }} \\
\hline & & & & & & \\
\hline Market Income (MI) & 0.793 & 0.636 & 0.975 & 0.819 & 0.026 & 0.000096 \\
\hline Direct Payments (DP) & 0.151 & 0.723 & 0.742 & 0.135 & -0.016 & -0.000316 \\
\hline $\begin{array}{l}\text { Net financial Benefits from } \\
\text { IST }\left(\mathrm{NB}_{\mathrm{IST}}\right)^{\wedge \wedge}\end{array}$ & 0.056 & 1.229 & 0.403 & 0.046 & -0.010 & -0.000512 \\
\hline \multirow[t]{2}{*}{ Farm income (IIP) } & \multirow{2}{*}{\multicolumn{6}{|c|}{ 2012-2014 }} \\
\hline & & & & & & \\
\hline Market Income (MI) & 0.801 & 0.628 & 0.973 & 0.829 & 0.028 & 0.000144 \\
\hline Direct Payments (DP) & 0.145 & 0.718 & 0.722 & 0.128 & -0.018 & -0.000496 \\
\hline $\begin{array}{l}\text { Net financial Benefits from } \\
\text { IST }\left(\mathrm{NB}_{\mathrm{IST}}\right)^{\wedge \wedge}\end{array}$ & 0.054 & 1.358 & 0.349 & 0.043 & -0.011 & -0.000805 \\
\hline Farm income (IIP) & & 0.590 & & & & \\
\hline
\end{tabular}

$\wedge$ Impact of an increase of 1000 Euro/farm

$\wedge \wedge$ Assuming that farmers pay contributions proportional to their income to cover $35 \%$ of the overall indemnification cost (IIP)

Source: Own elaborations on Italian FADN data 


\section{Acknowledgements}

We would like to thank the CREA-PB for allowing us to use the data on which the analysis has been developed. The views and opinions expressed in this paper are those of the authors and do not necessarily reflect the position of the CREA-PB.

\section{Authors' contributions}

SS has made substantial contributions to the conception and design of the analysis and has coordinated the work. GD and RF have made substantial contributions to its design. GD has developed the data analysis and, together with SS and RF, has interpreted the results. SS and GD have drafted the paper that has been substantively revised by RF. All authors have approved the submitted version.

\section{Authors' information}

Simone Severini is professor of agricultural economics and policy at Tuscia University, Viterbo (Italy). Giuliano Di Tommaso is collaborating with Tuscia University, Viterbo (Italy).

Robert Finger is professor and head of the Agricultural Economics and Policy Group, at ETH Zurich (Switzerland).

\section{Funding}

This research has been developed within the project "Towards SUstainable and REsilient EU FARMing systems" (SUREFarm). This project has received funds from the European Union's Horizon 2020 research and innovation program under grant agreement no. 727520

\section{Availability of data and materials}

The data analyzed in the current study are available from the Consiglio per la ricerca in agricoltura e l'analisi dell'economia agraria - Politiche e Bioeconomia (CREA-PB) of Rome (Italy) at: http://bancadatirica.crea.gov.it/Default. aspx. Restrictions apply to the availability of these data, which were used under license for the current study and so are not publicly available. Data are however available from the authors upon reasonable request and with permission of CREA-PB.

\section{Competing interests}

The authors declare that they have no competing interests.

\section{Author details}

${ }^{1}$ Tuscia University, Viterbo, Italy. ${ }^{2}$ Agricultural Economics and Policy Group, ETH Zurich, Zurich, Switzerland.

Received: 16 January 2019 Accepted: 9 October 2019

Published online: 20 December 2019

\section{References}

Bardají I, Garrido A (2016) State of play of risk management tools implemented by member states during the period 2004 2020: national and European frameworks. Study requested by the European Parliament's Committee on Agriculture and Rural Development. Bruxelles.

Cafiero C, Capitanio F, Cioffi A, Coppola A (2007) Risk and crisis management in the Reformed European Agricultural Policy. Canadian Journal of Agricultural Economics/Revue canadienne d'agroeconomie 55:419-441

Castañeda-Vera A, Garrido A (2017) Evaluation of risk management tools for stabilising farm income under CAP 2014-2020. Economía Agraria y Recursos Naturales 17(1):3-23

Chen CN, Tsaur TW, Rhai TS (1982) The Gini coefficient and negative income. Oxford Economic Papers, New Series 34(3): $: 473-478$

Ciliberti S, Frascarelli A (2018). The CAP 2013 reform of direct payments: redistributive effects and impacts on farm income concentration in Italy. Agricultural and Food Economics, 2018 6:19

Cordier J, Santeramo F (2018) Mutual funds and the Income Stabilisation Tool in the EU: Retrospect and Prospects. EuroChoices (December 2018)

Dell'Aquila C, Cimino O (2012) Stabilization of farm income in the new risk management policy of the EU: a preliminary assessment for Italy through FADN data. Paper presented at the $126^{\text {th }}$ EAAE Seminar: "New challenges for EU agricultural sector and rural areas. Which role for public policy?". Capri, Italy.

Efron B (1993) An introduction to the bootstrap. Chapman \& Hall/CRC, New York

El Benni N, Finger R (2013) The effect of agricultural policy reforms on income inequality in Swiss agriculture - An analysis for valley, hill and mountain regions. Journal of Policy Modeling 35(4):638-651

El Benni N, Finger R, Mann S (2012) Effects of agricultural policy reforms on income risks in Swiss agriculture. Agricultural Finance Review 72(3):301-324

El Benni N, Finger R, Meuwissen M (2016) Potential effects of the income stabilisation tool (IST) in Swiss agriculture. European Review of Agricultural Economics 43(3):475-502

Enjolras G, Capitanio F, Aubert M, Adinolfi F (2014) Direct payments, crop insurance and the volatility of farm income. Some evidence in France and Italy. New Medit 1:31-40

European Commission (EC) (2009) Income variability and potential cost of income insurance for EU. Directorate-General for Agriculture and Rural Development, Brussels, Belgium

European Commission (EC), 2010. Farm accountancy data network. An A to Z of methodology. Available at: http://ec.europa. eu/agriculture/rica/pdf/site_en.pdf.

European Commission (EC), 2018. A modern budget for a union that protects, empowers and defends. The Multiannual Financial Framework for 2021-2027. COM(2018) 321 final. Brussels, 2.5.2018.

Eurostat, 2013. Farm structure survey 2013 - main results. Available at: http://ec.europa.eu/eurostat/statistics-explained/index php/Farm_structure_survey_2013_-_main_results. 
Findeis JL, Reddy VK (1987) Decomposition of income distribution among farm families. Northeastern Journal of Agricultural Economics 16:165-173

Finger R, El Benni N (2014a) A note on the effects of the Income Stabilisation Tool on income inequality in agriculture. Journal of Agricultural Economics 65(3):739-745

Finger R, El Benni N (2014b) Alternative specifications of reference income levels in the income Stabilization Tool. In: Zopounidis C, Kalogeras N, Mattas K, Dijk G, Baourakis G (eds) Agricultural Cooperative Management and Policy. Springer

Finger R, Lehmann N (2012) The influence of direct payments on farmers' hail insurance decisions. Agricultural Economics 43(3):343-354

Fresco LO, Poppe KJ (2016) Towards a common agricultural and food policy. Wageningen University \& Research

Galán-Martín A, Pozo C, Guillén-Gosálbez G, Vallejo AA, Esteller L (2015) Multi-stage linear programming model for optimizing cropping plan decisions under the new Common Agricultural Policy. Land use policy 48:515-524

Hennessy DA (1998) The production effects of agricultural income support policies under uncertainty. American Journal of Agricultural Economics 80(1):46-57

lyer P, Bozzola M, Hirsch S, Meraner M, Finger R (2019) Measuring farmer risk preferences in Europe: a systematic review. Journal of Agricultural Economics. In Press. https://doi.org/10.1111/1477-9552.12325

Keeney M (2000) The distributional impact of direct payments on Irish incomes. Journal of Agricultural Economics 51(2):252-263

Kimura S, Antón J (2011) Farm income stabilization and risk management: some lessons from Agristability Program in Canada. Paper presented at the International Congress of the European Association of Agricultural Economists. Zurich, Switzerland

Lerman RJ, Yitzhaki S (1985) Income inequality effects by income source: a new approach and applications to the U.S. Review of Economics and Statistics 67:151-156

Liesivaara P, Myyrä S (2016a) The demand for public-private crop insurance and government disaster relief. Journal of Policy Modeling 39:19-34

Liesivaara P, Myyrä S (2016b) Income stabilisation tool and the pig gross margin index for the Finnish pig sector, in $90^{\text {th }}$ Annual Conference. Warwick University. Coventry, UK. No. 236360. Agricultural Economics Society.

Liesivaara P, Myyrä S, Jaakkola A (2012) Feasibility of the Income Stabilisation Tool in Finland. Paper prepared for the $123^{\text {rd }}$ EAAE Seminar Price Volatility and Farm Income Stabilisation. Dublin, Ireland.

Mary S, Santini F, Boulanger P (2013) An ex-ante assessment of CAP Income Stabilisation Payments using a farm household model. Paper presented at the $87^{\text {th }}$ Annual Conference of the Agricultural Economics Society, University of Warwick.

Matthews A (2010) Perspectives on addressing market instability and income risk for farmers, Discussion Paper No. 324/April 2010, Institute for International Integration Studies. Trinity College Dublin, Ireland.

Matthews A (2018) By how much is the CAP budget cut in the Commission's MFF proposals?. Available on line at: http:/ capreform.eu/.

Meuwissen MPM, Assefa T, Van Asseldonk MAPM (2013) Supporting insurance in European agriculture; experience of mutuals in the Netherlands. EuroChoices 12(3):10-16

Meuwissen MPM, Huirne RBM, Skees JR (2003) Income insurance in European agriculture. EuroChoices 2(1):12-17

Meuwissen MPM, Mey YD, Van Asseldonk MAPM (2018) Prospects for agricultural insurance in Europe. Agricultural Finance Review 78(2):174-182

Meuwissen MPM, Van Asseldonk MAPM, Huirne RBM (2008) Income stabilisation in European agriculture. Wageningen Academic Publishers, Wageningen, The Netherlands

Meuwissen MPM, Van Asseldonk MAPM, Pietola KS, Hardaker JB, Huirne RBM (2011) Income Insurance as a Risk Management Tool After 2013 CAP Reforms? EAAE Congress, Zurich, Switzerland

MIPAAF (Italian Ministry of Agriculture), 2017. Italy - Rural Development Programme (National). Version 5.0. Rome, 10/11/2017. Available at: https://www.reterurale.it/psrn.

Moro D, Sckokai P (2013) The impact of decoupled payments on farm choices: conceptual and methodological challenges. Food Policy 41:28-38 https://doi.org/10.1016/j.foodpol.2013.04.001

Payton ME, Greenstone MH, Schenker N (2003) Overlapping confidence intervals or standard error intervals: what do they mean in terms of statistical significance? Journal of Insect Science 3(34):1-6

Pigeon M, Henry de Frahan B, Denuit M (2012) Actuarial evaluation of the EU proposed farm income stabilisation tool. Paper prepared for the 123rd EAAE Seminar Price Volatility and Farm Income Stabilisation, 23-24 February. Dublin, Ireland.

Pyatt G, Chen C, Fei J (1980) The distribution of income by factor components. Quarterly Journal of Economics 95:451-473

Scheffé $H$ (1959) The analysis of variance. Wiley, New York

Severini S, Biagini L, Finger R (2018) The design of the Income Stabilization Tool in Italy: balancing risk pooling, risk reduction and distribution of policy benefits. Journal of Policy Modeling. https://doi.org/10.1016/j.jpolmod.2018.03.003

Severini S, Tantari A, Di Tommaso G (2016a) The instability of farm income. Empirical evidences on aggregation bias and heterogeneity among farm groups. Bio-based and Applied Economics 5(1):63-81

Severini S, Tantari A, Di Tommaso G (2016b) Do CAP direct payments stabilise farm income? Empirical evidences from a constant sample of Italian farms. Agricultural and Food Economics 4(6):1-17

Shields DA (2015) Federal crop insurance: background. Congressional Research Service. Report, Washington DC, pp 7-5700

Stark O, Taylor JE, Yitzhaki S (1986) Remittances and inequality. The Economic Journal 96:722-740

Trestini S, Giampietri E (2018). Re-adjusting risk management within the CAP: evidences on the implementation of the Income Stabilisation Tool in Italy. In: Wigier M, Kowalski A (Eds) (2018). The Common Agricultural Policy of the European Union - the present and the future EU Member States point of view. Institute of agricultural and food economics national research institute. Warsaw, Poland.

Trestini S, Giampietri E, Boatto V (2017). Toward the implementation of the Income Stabilization Tool: an analysis of factors affecting the probability of farm income losses in Italy. New Medit N. 4/2017: 24-30.

Trestini S, Szathvary T, Pomarici E, Boatto V (2018) Assessing the risk profile of dairy farms: application of the Income Stabilisation Tool in Italy. Agricultural Finance Review 78(2):195-208

Turvey CG (2012) Whole Farm Income Insurance. Journal of Risk and Insurance 79:515-540

\section{Publisher's Note}

Springer Nature remains neutral with regard to jurisdictional claims in published maps and institutional affiliations. 